\title{
The Empirical Side of the Power Elite Debate: an Assessment and Critique of Recent Research*
}

\author{
Harold R. Kerbo, California Polytechnic State University \\ L. Richard Della Fave, North Carolina State University
}

From the earliest writings in social science there have been lively debates over the extent to which societies are dominated by elites. Recently, empirical data have been considered for elite backgrounds, elite interlock, elite unity, and elite influence on public policy, but interpretation of the data continue to be problematic. The findings are often confusing and conflicting mainly because of differing methodologies, definitions and indicators of elite status. Focusing on the four areas of quantitative research listed, we compare the findings in an attempt to explain some of the conflicts. When possible, we have prepared summaries of the consistent findings, which tend to show, with respect to these issues, greater support for elite theories as opposed to pluralist theory. Finally we discuss some of the major questions in the debate that current research is unable to answer, and outline future research needs.

One of the longest running debates in the social sciences is over the nature of power stratification, a debate that can be traced back at least to the works of Marx, Mosca, Pareto, and others. Since the writings of C. Wright Mills (1956), however, the debate has become even more heated. And with the increased interest since the 1960s the opposing positions in the debate have become more complex. But, contrary to what we might expect, the new interest in the nature of power stratification, until recently, has not brought with it an increased level of systematic empirical research. We can suggest at least two reasons for the modest volume of research: first, the reality under study is often simply inaccessible (Mills, 1956:363); and second, the question is so politically significant that theorists too often have been influenced more by political values than by empirical research (Bachrach, 1967; Dye, 1976; Mankoff, 1970). The result has been ambiguous theories that make empirical research difficult.

In the past decade, however, we have witnessed a shift in the power elite controversy from a debate dominated almost completely by theory to one striking a more equitable balance between theory and empirical research. Like the shift toward pluralism which occurred in the 1950 s, allegedly due to changing value assumptions (see Bachrach, 1967; Walker, 1966), the changing assumptions in the late 1960s and early 1970s have led to an increased interest in elites (see Lowi, 1973:vii-ix). With an increase in the volume of empirical research, however, we find nearly as much disagreement on indicators, definitions, and parameters to be used in empirical studies of national elites as we do with respect to

\footnotetext{
* Revision of a paper presented at the annual meeting of the American Sociological Association, San Francisco, September, 1978. We thank Hermann Strasser, Richard Shaffer, and Kathy Kerbo for their helpful comments on this work, and Diane Goldman for her editing and typing of the manuscript. Harold R. Kerbo's address is: Department of Social Sciences, California Polytechnic State University, San Luis Obispo, California 93407.
} 
theory. As the debate becomes more focused on empirical questions, the old problem of differing elite concepts and indicators (Zuckerman, 1977) becomes more evident.

The present work is primarily devoted to a critical examination of recent quantitative research on the existence and power of national elites focusing on four key areas: elite backgrounds, elite interlock, elite unity, and elite influence on public policy. In each of these areas we will compare the findings, attempting to explain differences and contradictions. Finally, we will summarize the overall picture of elites suggested by the several sets of data, discuss the theoretical implications, and outline future research needs.

\section{Research on Elite Backgrounds}

Social class ties and other background characteristics of elites have been of interest. Much research has been concerned with religious, racial, sex, regional, and educational backgrounds of elites (for example, Prewitt and McAllister, 1976; Zweigenhaft, 1975), but the most important questions have involved the extent to which the top is open or closed to those from non-elite backgrounds, and the extent to which one segment of the society (such as an upper class) dominates elite positions. Though the correspondence between background, on the one hand, and attitudes, values, and behavior, on the other, is far from perfect, research has shown sufficiently strong correlations to make this line of research worthwhile (Edinger and Searing, 1967; Dye, 1976:149).

G. William Domhoff $(1967,1970)$ was one of the first to take up the research tradition left by the death of C. Wright Mills. The basis of Domhoff's (1967:143) model of a "governing class" is found in his "sociology of leadership method," which attempts to show that one of the most important means of upper class dominance is through holding key institutional positions in the society. Thus, much of his work involves identifying the class backgrounds of individuals in such positions. Domhoff specifies five major indicators of upper class membership (Domhoff 1970:21-27; also see Domhoff 1967:33-37): (1) a listing in one of the various blue books or the Social Register; (2) any male member of the family attending one of the elite prep schools; (3) any male member of the family belonging to one of the elite social clubs; (4) any female member of the family belonging to an elite club or attending an elite prep school; (5) and finally, upper class membership is assumed if the "father was a millionaire entrepreneur or $\$ 100,000$-a-year corporation executive or corporation lawyer" and the person attended an elite prep school or belonged to an exclusive club on an extended list of these schools and clubs. Identification with any one of these five categories places an individual on Domhoff's list of upper class membership.

Much of Domhoff's work is not systematic. Only with respect to a few positions has he been able to determine overall percentages of individuals from the upper class. Table 1 shows that among the top 15 to 20 financial, industrial, transportation, utility, and merchandising corporations, Domhoff (1967:51) found an overall majority of the directors of these corporations to be members of the upper class as defined by his indicators. For the government sector, he examined "key" cabinet posts. Covering a period from 1932-1964, Domhoff 
(1967:97-99) found five of eight Secretaries of State and the Treasury, and eight of thirteen Secretaries of Defense to be members of the upper class.

Recent work by Mintz (1975) and Freitag (1975) shows an impressive

Table 1. Findings on Corporate and Government Elite Backgrounds

\begin{tabular}{|c|c|c|c|c|c|}
\hline Study & $\begin{array}{c}\% \\
\text { Upper } \\
\text { Class } \\
\text { Membership }\end{array}$ & $\begin{array}{c}\% \\
\text { Business } \\
\text { Elite }\end{array}$ & $\begin{array}{c}\% \\
\text { Business } \\
\text { Elite or } \\
\text { Upper } \\
\text { Class }\end{array}$ & $\begin{array}{c}\% \\
\text { Members } \\
\text { of } \\
\text { Exclusive } \\
\text { Clubs }\end{array}$ & $\begin{array}{c}\% \\
\text { Previous } \\
\text { Corporate } \\
\text { Elite*** }\end{array}$ \\
\hline
\end{tabular}

1. Domhoff

Corporate Elite

Directors of top

20 industrials $\quad 54$

15 banks 62

15 insurance 44

15 transportation $\quad 53$

15 utilities 30

Government Elite (1932-1964)

Secretaries of State 63*

Secretaries of Defense 62

Secretaries of Treasury $\quad 63$

2. Mintz and Freitag

Cabinet Secretaries (from

1897-1973)

all cabinet $\quad 66.0$

Democrats $\quad 60.4$

Republicans $\quad \mathbf{7 1 . 3}$

all cabinet (with business elite $\quad 63.4$

only before cabinet)

all cabinet (with business elite $\quad 76.1$

before or after)

Democrats

73.6

78.1

all cabinet (this includes business

elite before or after cabinet)

all cabinet (this includes business

before and after)

90.0

54.6

3. Dye

Government Elite** 25

Corporate Elite 30

Government Elite $\quad 6$

Corporate Elite $\quad 44$

Government Elite

*Listing in Social Register indicating upper class membership.

**More expanded definition of government and corporate elite than Domhoff.

***Dye's corporate elite excludes corporate lawyer, Mintz and Freitag's business elite includes corporate lawyers. 
amount of systematic data concerning the corporate and social class ties of individuals in the executive branch of the Federal government. They compiled information on the background characteristics of all cabinet members serving thirteen Presidents from 1897 to 1973 (a total of 205 individuals and 358 positions). In terms of their indicators of business elite backgrounds, "an individual was considered a member of the business elite if he/she held a position as a director or officer of a major industrial corporation or non-industrial corporation (such as a bank, insurance company, utility, or transportation company) in the United States"; or an individual was considered a member of the business elite if "(1) the person was listed as a member of a corporate law firm in the MartindaleHubbell law directory; (2) the person was listed in a biographical source as having been a member of such a corporate law firm; or (3) a biographical narrative stated that the individual had served as a lawyer representing a major U.S. corporation" (Freitag, 1975:150). Mintz's (1975:133) indicators of upper class membership were similar to, but broader than, those used by Domhoff: "An individual was defined as a member of the social elite if he was listed in the Social Register; had attended one of an extremely small set of exclusive preparatory academies; had attended Harvard, Yale, or Princeton; was a member of one of the 105 social clubs listed in the front of the Social Register."

Freitag and Mintz report (see Table 1) that "Nearly $90 \%$ of all cabinet officials who held office in the period 1897-1973 were members of either the social or business elite ..." (Mintz, 1975:135). It should be noted that this figure includes those belonging to the business elite before or after the cabinet position. Further analysis shows that 54.6 percent were members of both, 63.4 percent were members of the business elite before the cabinet position, 76.1 percent were members of the business elite before or after, and 66 percent were members of the upper class before joining the cabinet (Mintz, 1975:135; Freitag, 1975:151). In addition, if the criterion of corporate lawyer is excluded, the number in the cabinet with business elite backgrounds before and after the cabinet position only drops to 62 percent (Freitag, 1975:141). These studies show a steady increase in business elite backgrounds (before and after) for cabinet members and little difference between Democrat and Republican administrations (Freitag, 1975:142-44). And a breakdown by cabinet posts shows all to have had a majority from the business elite-ranging from a high of 100 percent to a low of 53.8 percent for Secretaries of Labor (Freitag, 1975:147).

Thomas Dye's (1976; Dye and Pickering, 1974; and Dye, DeClercq, and Pickering, 1973) massive study of institutional elites in the United States provides an interesting contrast to the works of Domhoff, Freitag, and Mintz. We must begin with Dye's (see Dye and Pickering, 1974:901-5) indicators and measures of institutional elites. Included among the corporate elite are the directors and presidents (3,572 individuals) of the top corporations that control onehalf of the corporate assets in the nation (i.e., beginning with the top corporation and working down until one-half of the assets are included). This is done with industrial corporations, banks, insurance companies, utilities, communications, and transportation. For the government elite, Dye (1976:12) selects "the president and vice-president; secretaries, under-secretaries, and assistant secretaries of all executive departments; White House presidential advisors and ambassadors-at-large; congressional committee chairpersons and ranking minority 
committee members in the House and Senate; House and Senate majority and minority party leaders and whips; Supreme Court Justices; members of the Federal Reserve Board and the Council of Economic Advisors." In addition Dye includes top military officers and secretaries in the government elite for most of his analysis (total of 286 individuals in all, with 59 of these from the military).

Using the above indicators, Dye presents the following findings: 26.7 percent of the members of the government elite have held positions in the corporate elite (Dye, 1976:136); 16.6 percent of the government elite list their principle occupation as being in the corporate elite (Dye, 1976:159); 83.5 percent of the government elite have held a previous position in the government elite; 39.6 percent of the corporate elite have held previous positions in the government elite; and another 56.1 percent of the government elite have held positions in top law firms. Using indicators of upper class similar to those of Domhoff, Dye $(1976: 152)$ found 30 percent of the corporate elite and 25 percent of the non-military government elite to have upper class origins. Looking only to membership in exclusive upper class clubs from a list similar to Domhoff's, Dye (1976:164) found 44 percent of the corporate elite and 6 percent of the non-military government elite to be members.

In comparing these studies, their comparability must be considered. Beginning with the indicators of upper class membership, Domhoff's and Mintz's are broadly similar. The main difference is that Mintz includes attendance at Harvard, Yale, and Princeton and an expanded list of exclusive social clubs (see Mintz, 1975:133). Dye's indicators of upper class membership, however, present greater problems of comparability. While Dye (1976:151) claims to use Domhoff's basic indicators, he also includes parents' elite institutional position as an indicator of upper class membership. In another respect, however, Dye has a more exclusive definition of upper class membership. In the use of exclusive social clubs as an indicator, Domhoff includes four clubs not used by Dye (see Dye, 1976:164; Domhoff, 1970:23). Finally, Domhoff's listing of elite prep schools is slightly more inclusive than Dye's listing-37 versus 33 (Domhoff, 1970:22-33; Dye, 1976:154). It is impossible to estimate precisely the importance of Dye's differing indicators of upper class membership, but the differences do not appear large enough to prevent our arriving at some fairly firm conclusions.

Turning to indicators of corporate elite status, Dye and Domhoff differ in that Domhoff looks only to the 15 or 20 wealthiest corporations while Dye (1976: 20) looks to all of those controlling half of the assets in the particular area (100 of the top industrial corporations; 33 of the top corporations in transportation, communications, and utilities; the top 50 banks; and the 18 top insurance companies). This is not a serious problem, however, and in fact gives us an opportunity to compare the backgrounds of those at different "levels" of corporate elite status. Another difference is with Dye's inclusion of corporation directors and presidents in the business elite because Domhoff includes only the directors of the corporations. The most serious obstacles to comparability, however, are with the work of Mintz and of Freitag who include all top corporations (though they never say exactly how many they include in the top-see Freitag, 1975: 140 ) and consider the elite to consist of the directors and "officers" of these corporations (again, they do not mention how far they go in including officers- 
see Freitag, 1975:140). Also, Mintz and Freitag include corporate lawyers in the business elite while Dye and Domhoff do not. The effects of the inclusion of corporate lawyers by Mintz and Freitag, and their exclusion by Dye, cannot be determined (mainly because of Dye's larger definition of the government elite). We can see that this has only a minimal effect on Mintz and Freitag's findings, however, when we note that the cabinet ties to the business elite dropped only from 76.1 percent to 62 percent when corporate lawyers are excluded (Freitag, 1975:141).

Finally, we must consider the differing indicators of membership in the government elite. While Domhoff looks only at a few cabinet positions (from 1932 to 1964), Freitag and Mintz include the entire cabinet (from 1897 to 1973), while Dye has an inclusive definition. These differences should not concern us because they refer to differing levels within the government elite. The only significant problem in our estimation, is that Dye's indicator is too broad, including the military elite as part of the government elite throughout most of his analysis. There are clear differences in the recruitment patterns and background of military as compared to civilian leaders (Dye, 1976:152, 154, 159). Thus, because the military makes up 21 percent of his total government elite when possible we have dropped the military from the figures presented here.

Despite these problems, we can draw the following conclusions about the backgrounds of corporate and government elites: (1) Domhoff's estimation of a high proportion of cabinet members having upper class background is reinforced by Mintz's study; (2) As the corporate elite is defined in more restrictive terms, the higher the percentage recruited from upper class backgrounds (this was suggested, but not followed up by earlier studies of elite backgrounds-for example, see Keller, 1963:209-10, 319); (3) Viewing the President's Cabinet as the top of the government elite, Mintz's data show a high percentage of individuals from the upper class (66 percent to 25 percent in Dye's expanded government elite). Thus, upper class backgrounds increase as more limited indicators of a government elite are used; (4) When looking to corporate elite backgrounds among members of the government elite corporate backgrounds appear more prevalent the more restrictive the definition of the government elite is (63.4 percent to 26.7 percent with Dye's larger government elite), and the more inclusive the definition of the corporate elite is (i.e., Freitag's definition).

\section{Elite Interlock}

Elite interlock can be described as the situation in which an individual simultaneously holds two or more elite positions. This is different from the study of elite backgrounds because in the case of elite backgrounds we are dealing with the previous characteristics of, or institutional positions held by, an elite individual (a dynamic view); but with the study of elite interlock we are concerned with the overlap between elite positions at one point in time (a static view). An examination of elite interlocks is a subject of major concern for students of national power distribution because the more numerous the interlocks, the greater the number of key positions held by the same individuals; thus, the more power is concentrated in the hands of a few individuals or positions.

Dye (1976:134) examined the extent of interlock between the government 
and other elite positions and greatly emphasized the fact that only 19.4 percent of the government elite positions in his study are so interlocked. Most of these positions (91.2 percent) are in what he calls the public interest sector. This is hardly surprising when we consider that government officials are prevented from holding other positions which will result in conflicts of interest. To study ties between government and corporate elites, one must, therefore, examine elite backgrounds (or dynamic interlocks) as has been done by some of the researchers discussed in the previous section of this paper. For this reason we will restrict our concern in this section to interlocks within the economic sector.

As Sonquist and Koening (1975:196) put it, "It is important to focus attention on the specific nature of interlocks because an understanding of the relationships between interlocking firms can tell us much about the dynamics of power and control in the U.S. political economic system." This is especially critical when we consider the extent to which the economy is dominated increasingly by a smaller number of giant corporations. For example, as Dye's (1976: 20) data show, in 1970 , more than 50 percent of the industrial assets are controlled by 100 of the more than 200,000 corporations. The greater importance of interlocks with top corporations is also indicated by research which shows that the corporations on top today, contrary to those on top in the past, are more likely to stay on top (Mermelstein, 1969:536). Also important in this question of economic concentration is the new data showing that just 21 corporate investors are found in the top 5 stockholders in over half of the top 122 corporations (Subcommittee of Governmental Affairs, 1978:1). Thus, the number of interlocks among these top corporations becomes increasingly important.

Turning first to Dye's $(1973,1974,1976)$ recent research, we note that " $44 \%$ of all top corporate positions were interlocked with other top positions" (see Table 2). Most of the interlocks involving incumbents of top corporate positions were within the corporate sector ( 72 percent) rather than with other sectors. Though they would be interesting, no figures are given by Dye on how many individuals account for this 44 percent interlock in positions. What we do know is that while 40 percent of all positions (government, corporate, and public interest sectors) are interlocked, only 20 percent of the 4,101 individuals account for these interlocked positions; and there is a lifetime average of 11.1 elite positions held by corporate elite individuals (Dye, 1976:130, 135). Because Dye's data include only the top 100 corporations, he cannot say how many of the corporate elite are interlocked with corporations below the top 100. In addition, it would be interesting to know the amount of interlock among corporate directors only (excluding corporate presidents), and the pattern and types of interlocks among the various corporations.

A recent study by Allen (1974) answers a few of these questions. Allen (1974:399) examined the amount of interlock among the directors of the 200 largest nonfinancial corporations and 50 largest financial institutions and found (see our Table 2) that these corporations and financial institutions had an average of 10.41 interlocks in 1970 . This was also divided to show that the average was 16.92 for the financial institutions, 9.62 for the industrial corporations, and 7.41 for the remaining nonindustrial corporations. Also of interest is that the amount of assets held was strongly correlated with the number of interlocks (.57), even when the differing size of the directorate is controlled $(.49$, larger 
Table 2. Economic Elite Interlock (Static View)

Study

Findings

1. DYE

Total Corporate Interlocks* (positions with interlocks)

$44.0 \%$

Of Total Interlock

percent to other corporate positions

$72.7 \%$

percent to public interest positions

$25.9 \%$

percent to government positions

$0.2 \%$

2. ALLEN (1970 Data)**

Average interlocks of corporations

10.41

Average interlocks of financial institutions

16.92

Average interlocks of industrial corporations

9.62

Average interlocks of non-industrial corporations

7.41

3. DOOLEY (1965 Data)**

Average interlocks of corporations

Average interlocks of financial institutions

Average interlocks of industrial corporations

Average interlocks of non-industrial corporations

Average interlocks to size of corporation***

less than .5 billion assets

1.0 to 1.4 billion assets

1.5 to 1.9 billion assets

3.0 to 3.9 billion assets

16.4

5.0 and over billion assets

*Top 100 industrial, 50 banks, 18 insurance, 33 transportation, communication, and utilities in 1970 (board of directors and presidents).

**Top 200 non-financial and top 50 financial corporations (board of directors).

*** Selected categories from Dooley's table.

corporations having more interlocks). (See Allen, 1978 which was in press simultaneously with this paper.)

Another interesting study is Dooley (1969:314) who collected data on the interlocks among the boards of directors in the top 250 corporations (200 nonfinancial and 50 financial). By comparing his data from 1965 with a similar set for 1935, Dooley found that the number of interlocks were about the same (225 in 1935 and 223 in 1965, Dooley, 1969:315). In comparing Dooley's data with Allen's (for 1970) we find that larger corporations have more interlocks than smaller ones (see our Table 2). Dooley (1969:316) lists a progressively increasing number of interlocks from smaller to larger corporations (see our Table 2 ). Thus, much like the findings on the upper-class backgrounds of elites, as we move closer to the top we find more interlocks. Also of interest is Dooley's (1969:317) finding that by excluding board members who also hold executive positions within the corporation, the average number of interlocks with remaining board members is greatly increased. Soref's (1976) findings confirm that these men whose power comes through ownership, rather than executive position in the corporation, are more likely to have upper class backgrounds, are 
more concerned with major decisions, and are able to spread a web of influence to a larger number of corporations. We are, however, nowhere near solving the debate between those who argue that the board of directors have more power (see Soref, 1976:360) and those who argue that the executive officers hold more power (see Pfeffer, 1972; also see Zald, 1969; Seider, 1977).

Finally, Dooley's (1969:316) findings show the number of interlocks involving financial institutions are much higher for financial (15.2) than for industrial (9.1). Allen's (1974:399) 1970 data show even more extensive financial interlocks (16.9 average), with the 1935 financial interlocks least frequent (14.8 average). This seems to indicate the growing importance of financial institutions in the economy (see Subcommittee on Governmental Affairs, 1978). Allen (1974:399) argues, however, that this is related to the greater size (in terms of assets) of the financial institutions. But, the fact remains that their sphere of influence is greater. In identifying 15 "tight-knit" groups (in terms of number of interlocks) in his 1965 data, Dooley (1969:320) finds these groups have a recurring pattern: at the centers or hubs are found top financial institutions. And also of interest is the recent findings on what can be called "indirect interlocks" (Bunting, 1976a,b), a situation in which two corporations are tied, not directly but through interlocks to a common third corporation. These are found to be increasing recently, and with a majority of the host corporations (third corporation or midpoint) in the financial sector (Bunting, 1976a:34).

In related research, Sonquist and Koening (1975:204) began their work with Fortune's top 797 corporations in 1969 (including 11,290 directorships), but later reduced this number to 401 corporations by including only those with at least double interlocks. Using Levine's (1972) sociometric method, four types of corporations were identified: isolates, trivial dyad members, satellite cliques, and central cliques (Sonquist and Koening, 1975:206). Of the last, 32 major central cliques were identified for further analysis (details on all of these are contained in their appendix). Of special interest are the financial cliques. These tend to expand outward toward satellite cliques, while the non-financial cliques were more self-contained. One of the most important recent findings on the increasing power of financial institutions in the economy shows that financial institutions have influence not only through interlocks with other corporations but also through the control of voting shares of stock in major corporations (Subcommittee on Governmental Affairs, 1978). The proportion of stock ownership by institutions is increasing rapidly, and it is financial corporations who often hold voting rights with this stock. In 1976, banks, investment companies, and insurance companies held 34.8 percent of the voting rights of all corporate stock in the United States (Subcommittee on Governmental Affairs, 1978:14). This of course brings up an interesting question of who controls the voting stock in the major banks. In their study, the Subcommittee on Governmental Affairs (1978:260) found, "the principal stock voters in large banks are-large banks." The most important seems to be Morgan and Company which is the number one stock voter in five of the top banks in the nation (Bankamerica, Citicorp, Manufacturers Hanover, Chemical N.Y. Corporation, and Bankers Trust N.Y.).

In comparing these studies we find few problems with incompatible indicators such as those encountered with the elite background research (with the exception of Dye's research which includes corporate executives with directors). The 
most significant findings relating to the nature of corporate interlocks include the following: (1) The extent of interlock among corporate directors is fairly high, and has remained so through this century; (2) Directors who are not also executives in the corporation are more likely to be involved in these interlocks; (3) The larger the corporation the more interlocks; (4) A few powerful and important cliques can be identified within this mass of interlocks, with large financial institutions often at the center of these cliques; and (5) The average number of interlocks leading from financial institutions has been growing steadily, at least since 1935 .

\section{Elite Unity}

The existence of elite unity or cohesiveness is of central importance for those who argue from a ruling class or "governing class" position. Given this importance we would expect much research on the question, but that is not the case. We might conclude that some basis for unity exists when recalling the findings showing the upper class backgrounds of many elite individuals. But both sides agree that common background alone is not enough. With the exception of a few case studies (for example Baltzell, 1958), little has been done empirically on this question until the recent work of Domhoff.

Domhoff's (1974) most noted research in this area, in which he uses qualitative and quantitative methods, is contained in his study of San Francisco's Bohemian Club and Retreat. He attempts to demonstrate the upper class nature of this organization. Through an examination of the membership he finds 27 percent to be members of the "most exclusive club" in San Francisco, the Pacific Union Club. He argues that 38 percent of the resident members belong to the upper class. In addition, Domhoff (1974:30) found 45 percent of the 411 "nonresident regular members" listed in other upper class "blue books." And finally, Domhoff (1974:31) interprets as a tie to the corporate elite the figures which show "that at least one officer or director from 40 of the 50 largest industrial corporations in America was present" at the Bohemian Grove retreat in one year, along with directors of 20 of the top 25 commercial banks, 12 of the top 25 life insurance companies, 10 of the top 25 in transportation, and 8 of the 25 top utilities. In total, 29 percent of Fortune's top 797 corporations "were 'represented' by at least one officer or director" (Domhoff, 1974:32).

Domhoff attempts to show, through qualitative methods, that the members of these organizations gather not only to relax and socialize, but also to devote their time to shaping "consensus" on common business and political problems (see for example, 1974:15-18). More interesting for our purposes, however, are his attempts to show membership interlock between the various clubs and upper class organizations (Domhoff, 1974:105; 1975:178). With a statistical method for measuring the "centrality" of a club or organization in the total matrix (i.e., the extent to which an organization interlocks with many other organizations), he is able to list what he claims are the most important upper class clubs and organizations in the United States. By using this listing of top organizations he finds that 673 of Fortune's top 797 corporations have at least one connection to at least one of just 15 clubs and upper class organizations. In Domhoff's (1975: 
179 ) words, "this finding is even more impressive when we consider only the top 25 corporations in each category. Here we see that 25 of 25 industrials, 25 of 25 banks, 23 of 25 insurance companies, 24 of 25 transports, 24 of 25 utilities, 19 of 25 retails, and 18 of 25 conglomerates are connected."

Not everyone is convinced by Domhoff's work, however. One of the skeptics is Thomas Dye (1976:164; also our Table 1) whose data also show a great deal of membership in social clubs in general ( 75 percent), and 37 elite clubs in particular (44 percent). But his data also show that only 38 percent of the nonmilitary government elite belong to these clubs, with only 6 percent belonging to any of the 37 exclusive clubs. In reflecting on these findings, and those of Domhoff, Dye (1976:163) writes, "It is our judgment that club membership is a result of top position-holding in the institutional structure of society rather than an important independent source of power ... the clubs merely help facilitate processes that occur anyway." Dye (1976:163) believes the low membership of the government elite "undercuts the importance attributed to club membership by many 'power elite' writers."

In assessing Dye's position, it is difficult to see how he can dismiss the significance of club memberships by saying that this is only a "process that would occur anyway." Domhoff has never maintained that club membership is an "independent source of power." Rather, Domhoff's argument is only that such membership is a source of unity and consensus formation. Finally, although Dye finds that the government elite lacks participation in elite clubs, a close reading of Domhoff's (1974:18) list of speakers at the 1970 gathering at the Bohemian Grove suggests that though the government elite may not be members of these organizations, they do have an important role.

Domhoff's most serious error is his overestimation of the significance of his findings (see Domhoff, 1974:87; 1975:175). First, his study of the Bohemian Grove is only one piece to the puzzle. Also, his data often are not impressive (see McNall, 1977) in terms of the percentages of overlap in these clubs (see Domhoff, 1974:105). The most important question, of couse, is how much unity and consensus is actually created and maintained through these organizations? This, no doubt, is difficult to measure, and all Domhoff is able to do at this point is suggest that the findings from psychological studies on how group solidarity is formed support his conclusions (Domhoff, 1974:89-90). What we need are more direct measures of the effects of participation in these elite organizations.

\section{Elite Influence on Government Policy}

In this section we consider the economic elite's ability to shape government policy. Much of the research we have already discussed assumes that the relationships are important because of their effects on government policy. But, it is argued, the economic elite has other means of influence. It is here that we find a stress on upper class "policy forming organizations" such as the Council on Foreign Relations, the Committee for Economic Development, the Business Council, and others such as wealthy foundations and elite sponsored research in major universities (see Domhoff, 1974). For as Dye (1976:191) points out, it 
is by these means that "corporate and personal wealth provides both the financial resources and the overall direction of policy research, planning and development."

The first question involves the upper class and corporate elite membership and interlock in these "policy forming organizations." Domhoff attempts to demonstrate their elite membership in two ways. First he shows the upper class status of particular organizations. Domhoff (1970:116) finds that half of the 1400 members of the Council on Foreign Relations (CFR) are listed in the Social Register. But with the other organizations Domhoff is content mainly with showing their interlock with upper class clubs. His matrix of overlapping members (see Domhoff, .1975:178) shows (to name a few) the Business Council (.63, $.57, .44, .49)$, the Committee for Economic Development $(.58, .49, .46, .47)$, and the Council on Foreign Relations $(.37, .34, .24, .64)$, to have a great deal of overlap with just four elite clubs (Pacific Union, Bohemian Club, California Club, and Centurary Association). One of these organizations (the Business Council) is selected for special attention. Domhoff (1974:107) finds that 154 members of this organization (those members listed in Who's Who for 1971-72) hold 730 directorships in 435 banks and corporations. And finally, with a method to determine the "centrality" of several clubs and organizations (Domhoff, 1975:177-78), five of these policy organizations are listed in the top ten (with the Business Council listed as number one).

For upper class ties to the major foundations, Domhoff (1967:65) finds that of the top 13 (in terms of assets), two-thirds of their trustees are members of either the upper class (51 percent) or boards of major corporations (15 percent). For the universities, Domhoff (1967:78-79) is able only to present findings from another study done in the mid-1930s showing that one-third of the trustees of 30 "major" universities were listed in the Social Register and another 45 percent were directors or executives in major corporations.

In attempting to assess Domhoff's work on the question of how these organizations are able to influence government policy we must be aware that he is able to rely only on a few "case studies." An example of one type of research needed in this area can be found in the work of Shoup (1975), who provides an historical analysis of the Council on Foreign Relations, how the CFR was established by upper class individuals, and its impact on major decisions during WW II and later.

But for quantitative data in this area we return again to Thomas Dye (1976: 216) who argues that the pluralist view has been too simplistic: "The federal law-making process involves bargaining, competition, and compromise, as generally set forth in 'pluralist' political theory. But this interaction occurs after the agenda for policy-making has been established and the major directions of policy changes have already been determined." It is interesting to note that Dye rejects Domhoff's ruling class type theory. Although Dye claims not to be working from any particular model or theory of elites, several statements by Dye clearly suggest that he accepts a model very close to Keller's (1963) "strategic elites" (for example, see Dye, 1976:3-6).

With Dye's massive data on elite backgrounds and interlock we find an ambiguous category of elites he calls the "public interest" sector, which includes individuals from top law firms, directors of major foundations, trustees of elite 
universities, directors of "civic organizations" (such as the Council on Foreign Relations, the Committee for Economic Development, the Brookings Institution, and cultural organizations such as the Metropolitan Museum of Art) and presidents and directors of the major mass media. Dye's data contains a division in this sector which enables us to look at his findings on foundations, elite universities, and "civic" organizations separately. Dye creates a problem by including "cultural organizations" such as the Metropolitan Opera in this "civic organization" category, and because he does not tell us how many of the individuals examined in this category come from the "cultural organizations," we cannot estimate the bias produced.

The total interlock between directors of these organizations and other elites is quite high. With other elite positions, there is a 52.9 percent interlock with foundation directors, 32.9 percent with university trustees, and 42.9 percent with directors of civic organizations. Overall, the interlocks from these institutions are with corporate elites (58.8 percent), other public interest positions (60.4 percent), and government positions (4.7 percent according to Dye, 1976:134). It must be noted that these figures included individuals from top law firms as well as foundations, universities, and civic organizations. Among foundation directors, there is an average of 5.2 previous positions in the corporate elite, while the figure for university trustees is 3.6 , and for civic organization directors it is 4.4 (Dye, 1976:136). Finally, Dye (1976:152) finds 42 percent of the directors from the foundations, 25 percent from the elite universities, and 40 percent from the civic organizations to be members of the upper class, and 50 percent of the directors from the foundations, 62 percent from the elite universities, and 66 percent from the civic organizations were members of at least one of the $37 \mathrm{ex}-$ clusive clubs listed by Dye (1976:164).

Assessing the recent research in the area of elite influence on government policy, there are at least five major questions that need consideration: (1) the extent of elite control of "policy forming institutions"; (2) how the ideas or policy recommendations from these institutions get to the government; (3) funding sources of these institutions; (4) the general policies of these institutions themselves; and (5) how often the ideas and policy recommendations produced by these institutions are put into practice or written into law by the government. As the research discussed in this section shows, we have some useful data on question 1, some limited information (mainly from Domhoff, 1967; 1970) on question 3, much discussion, but little data on question 2 , and almost nothing on questions 4 and 5.

\section{Discussion}

Though much additional research is needed, and we have not been able to consider research on many points in the power elite debate, we believe some important conclusions can be drawn from the data. A major question is this: Do the findings lend more support to the pluralist or the elitist side of the debate? Despite Dye's $(1976: 11,145)$ repeated statements that his data can be used to support either side, by refining his indicators of elite status and combining his findings with those from other works reviewed here, the weight of evidence appears to fall on the side of the elitists. It is important to recognize, however, that 
there is a variety of elite theories, ranging from "conservative" to "critical." The present evidence is certainly not sufficient to offer unequivocal support for either of these elite theories.

It is safe to say that no matter how elite status is measured, not only are persons of elite background found in key positions far out of proportion to their representation in the population, but in some cases, for example the cabinet posts studied by Freitag, they comprise a majority of the incumbents. Clearly discernible patterns of intercorporate interlock and influence centering around major financial institutions have been discovered. So have widespread linkages between major corporations and several exclusive clubs, as well as patterns of disproportionate elite input into policy formulating organizations that have the ear of government.

Still, the meaning of these findings is not altogether clear. For instance, the pluralists claim that governmental decision making is a complex process that involves the interplay of countervailing pressure groups. The crucial question is whether or not the extent of elite overrepresentation in high governmental positions and policy formulating organizations, corporate interlock and involvement in exclusive social clubs is sufficient to upset the power balance among competing interests. Is it sufficient to insure that an elite (or a coalition of three elites in the case of Mills' thesis) can and does have its way on decisions it considers vital to its interests even against the opposition of a broad range of pressure groups representing the interests of the majority of the population?

This question immediately gives rise to others. How much elite overrepresentation would it take to insure such dominance? Do those of elite background who occupy high-level posts act on behalf of ingroup interests or do they act in a neutral manner in keeping with their official, governmental role obligations? In some of the most vital policy areas such as foreign affairs and the management of the economy, exactly which policies benefit which segments of the population? If elites do dominate, how does one explain the rise of reforms which, at least ostensibly, are opposed by elites (see Mintz et al., 1976; Mollenkopf, 1975)? None of these questions can be answered by the findings reviewed in this paper. Nevertheless, they are central to the larger debate over the distribution of power in American society, and thus a few suggestions as to how they might be attacked will be taken up later.

In our view, the patterns of interlock and overrepresentation that appear repeatedly in the studies reviewed here are sufficient to cast serious doubt upon the pluralist view of power in America. Given the conflict oriented assumptions of the pluralists (Kerbo, 1975, 1976) concerning human nature, it is incumbent upon them to explain how and why any group would not use to the fullest extent the opportunities offered by disproportionate representation in key positions. While this does not imply that an elite exercises total dominance, it suggests that if opposition is to have any hope of being effective, it would have to be extremely broadbased and highly mobilized, conditions that are met only infrequently.

A similar burden of proof is on the pluralists with respect to elite interlock and unity of purpose. The patterns of interlock, both those cutting across industries and centering about commercial banks (Subcommittee on Governmental Affairs, 1978; Levine, 1972) as well as those among "competitors" within a single industry (Scheuerman, 1975) raise serious questions about the role of 
competition versus coincidence of interest among segments of the business community. Research on the National Association of Manufacturers (Burch, 1973) and the U.S. Chamber of Commerce (Collins, forthcoming) suggests that there is a strong disagreement between big business and small to medium-sized firms over such basic issues as the extent of government intervention in the economy. The former is much more tolerant than the latter, because big business would find it easier to turn such intervention to its own advantage. And we are still left with big business equipped with extensive networks of interlock. Again, it is necessary for pluralists to explain why these networks would not be used to promote the collective interests of big business. Specifically, they could be used to generate and maintain tacit understandings that would lead to distribution of shares of the market, consequent suppression of aggressive price competition, cooperation in pressing the government to minimize the tax burden on industry (see Salamon and Siegfried's 1977 findings) and those with large property holdings, and channeling government intervention in the economy to favor the largest firms in particular industries. All of these things would promote the concentration of purchasing power away from the general public by preventing competitive pressures to lower consumer prices. They would also make it easier for business to pass on cost increases to the consumer in the form of higher prices and frustrate any move toward an effectively progressive tax system. We are arguing, again using the pluralists' own assumptions, that it is in the interests of major corporations to neutralize the disciplinary pressures of the market upon them. Extensive interlocks could greatly facilitate the effective pursuit of such interests (Herman, 1973).

This brings us directly to the issues that divide the two principal types of elite theorists, the "conservatives" (Dye, 1976; Putnam, 1976; Prewitt and Stone, 1973; Keller, 1963; Baltzell, 1958) and "critical" theorists (Anderson, 1974; Birnbaum, 1969; Bottomore, 1966; Domhoff, 1974, 1970, 1967; Miliband, 1969; Mills, 1956). Unlike the pluralists (i.e., Dahl, 1961, 1967; and Rose, 1967), both of these approaches acknowledge the centralization of political and economic power. Where they disagree is on the issue of in whose interests that control is exercised, and on whether or not such concentration of power is inevitable (Kerbo, 1975). Disputes between those two schools of elite theory often center around the question of whether one should focus upon collective issues as opposed to distributive ones. "Conservatives" see inequality as an inevitable aspect of complex societies, stemming from their functional needs of organization, and not the result of conspiratorial or capricious elite decision making. The "critical" theorists maintain, however, that such inequality is not inevitable, at least not on a scale anywhere close to what presently exists.

But here we come to a division within the critical elitist camp itself. On the one hand, there are the instrumentalists (Domhoff, 1974, 1970, 1967; Freitag, 1975; Mintz, 1975) who focus their attention on the question of who occupies powerful positions and who is linked with them, research that we have been reviewing in this paper. On the other hand, there are the structuralists (Harrington, 1976, 1970; Parkin, 1971; Poulantzas, 1975) who argue that it matters little who makes the decisions. As long as the economic system is based upon private ownership and the criterion of the profitability of the individual firm, and as long as there is public pressure from all strata on politicians to keep the 
economy thriving, the range of decisions that any "realistic" and "responsible" politician can make is restricted narrowly to those which promote the profitability of business. This, the structuralists argue, explains not only why the distribution of income has remained relatively constant throughout this century in both the United States and in Western Europe, but also why such inequality will necessarily be perpetuated in the future. Only a transformation of the economy into one based upon providing for human needs rather than profitability (in Marx's terms, use values instead of exchange values) is seen as capable of eliminating the gross inequalities that exist.

If present disagreements between "conservative" and "critical" elite theorists and between instrumentalists and structuralists within the "critical" camp are to be submitted to an empirical test, we must devise new research strategies. Especially if we are to compare what is with what could be we must turn to more sophisticated historical and comparative methods. Domhoff (1970) has attempted to use historical methods in a limited way, and Putnam (1976) has attempted to use comparative data. Both have been hampered, however, by numerous problems, especially a lack of comparable data.

\section{Program for Future Research}

We need to consider what must be done if the debate over the distribution of power on a national level is to progress beyond the state in which we now find it. It will be helpful if we explore generally the problems of theory building and testing.

Hage (1972:13) believes that little intellectual progress was made in fields such as biology until that "field shifted from non-variable to general variable concepts." Hage (1972:10) uses the example of democracy: "Democracy is an either-or phenomenon, a specific non-variable or categorical concept-regardless of the number of indicators we might have, the concept categorizes a society or political system as being democratic or not democratic." It is obvious that at present, the power stratification debate has been viewed in precisely these terms. A first step is to conceptualize the debate in terms of degrees of elite domination. Second, we must keep in mind several dimensions or aspects of elite domination or pluralist competition, four of which we have treated in this paper, and each of which must be treated as a continuum.

This type of research, however, will only be able to tell us what presently exists (i.e., degree of elite membership in the upper class, degree of elite unity, etc.). It can tell us little about the inevitability of elite rule or the outcome of degrees of elite domination. For answers to these questions we must turn eventually to historical and comparative analysis. And once we have moved to general variable concepts, we will be in a better position to benefit from comparative analysis. At the same time, once we have come to some agreement and have perfected our indicators for the dimensions involved in the debate (as we have attempted in this paper), we will be able to generate comparable data across societies.

An example of what we are suggesting here is in order. Let us take the issue of ties between corporate and governmental elites. If the degree of elite concentration makes little or no difference in the degree of inequality, then the struc- 
turalist argument gains credence. If, however, there is an inverse correlation between these variables, then the instrumentalist position is strengthened. Such findings also would be relevant to the "conservative"-"critical" controversy among elite theorists though not so clearly as in the case of the structuralists and instrumentalists. For example, if the degree of elite concentration shows little or no correlation with the degree of inequality, "conservatives" could argue that it demonstrates that elites are not especially exploitative, and that the inequality that exists probably constitutes an irreducible minimum for advanced industrial societies. If, however, a positive correlation between elite concentration and inequality is discovered, the "critical" theorists could claim support for their position.

No doubt the type of research described above will not be without problems. One of the greatest difficulties will be finding societies that are comparable in most respects, so that we know that variance found in one factor, such as class differences in income or working conditions, is at least partially explained by the variance in the extent of corporate and government elite ties. But until attempts are made in perfecting this type of analysis, we will have little chance of resolving many of the issues separating the various sides in the debate.

\section{REFERENCES}

$\rightarrow$ Allen, Michael. 1974. "The structure of interorganizational elite cooptation: interlocking corporate directorates." American Sociological Review 39:393-406.

$\rightarrow$. 1978. "Continuity and change within the core corporate elite." The Sociological Quarterly 19:51021.

Anderson, Charles H. 1974. The Political Economy of Social Class. Englewood Cliffs, N.J.: Prentice-Hall. Bachrach, Peter. 1967. The Theory of Democratic Elitism. Boston: Little, Brown.

Baltzell, E. Digby. 1958. Philadelphia Gentlemen. New York: Free Press.

Birnbaum, Norman, 1969. The Crisis of Industrial Society. New York: Oxford University Press.

Bottomore, Thomas B. 1966. Classes in Modern Society. New York: Vintage Books.

Bunting, David. 1976a. "Corporate interlocking, part II: the modern money trust." Directors and Boards $1: 28-36$.

— 1976b. "Corporate interlocking, part IV: a new look at interlocks and legislation." Directors and Boards 1:39-47.

Burch, Philip. 1973. "The N.A.M. as an interest group." Politics and Society 4:97-130.

Collins, Robert M. (forthcoming). "Positive business responses to the new deal: the roots of the Committee for Economic Development, 1933-1942.” Business History Review.

Dahl, Robert. 1961. Who Governs? New Haven: Yale University Press.

- 1967. Pluralist Democracy in the United States. Chicago: Rand McNally.

Domhoff, G. William. 1967. Who Rules America? Englewood Cliffs, N.J.: Prentice-Hall.

1970. The Higher Circles. New York: Random House.

1974. The Bohemian Grove and Other Retreats. New York: Harper.

1975. "Social clubs, policy-planning groups, and corporations: a network study of ruling-class cohesiveness." The Insurgent Sociologist 5:173-84.

$\rightarrow$ Dooley, Peter. 1969. "The interlocking directorate." American Economic Review 59:314-23.

Dye, Thomas R. 1976. Who's Running America? Englewood Cliffs, N.J.: Prentice-Hall.

Dye, Thomas R., Eugene Declercq, and John Pickering, 1973. "Concentration, specialization, and interlocking among institutional elites." Social Science Quarterly 54:8-28.

$\rightarrow$ Dye, Thomas R. and John Pickering. 1974. "Governmental and corporate elites: convergence and differentiation." Journal of Politics 36:900-925.

$\rightarrow$ Edinger, Lewis, and Donald Searing. 1967. "Social background in elite analysis: a methodological inquiry." American Political Science Review 61:428-45.

Freitag, Peter. 1975. "The cabinet and big business: a study of interlocks." Social Problems 23:137-52. 
Hage, Jerald. 1972. Techniques and Problems of Theory Construction in Sociology. New York: Wiley. Harrington, Michael. 1970. Socialism. New York: Saturday Review Press.

- 1976. The Twilight of Capitalism. New York: Simon and Schuster.

Herman, Edward, 1973. "Do bankers control corporations." Monthly Review 25:12-29.

Keller, Suzanne. 1963. Beyond the Ruling Class. New York: Random House.

Kerbo, Harold R. 1975. "Paradigms of social stratification: the contemporary power elite debate." Unpublished Ph.D. dissertation, Virginia Polytechnic Institute and State University.

1976. "Pluralism or ruling class: a case of paradigm conflict." Paper presented at the annual meeting of the American Sociological Association, New York City.

$\rightarrow$ Levine, Joel. 1972. "The sphere of influence." American Sociological Review 37:14-27.

Lowi, Theodore J. 1973. "Foreword." Pp. vii-xii in Kenneth Prewitt and Alan Stone (eds.), The Ruling Elites. New York: Harper and Row.

Mankoff, Milton. 1970. "Power in advanced capitalistic society: a review essay on recent elitist and Marxist criticism of pluralist theory." Social Problems 17:418-30.

McNall, Scott. 1977. "Does anybody rule America?: a critique of elite theory and method." Paper presented at the annual meetings of the American Sociological Association, Chicago.

Mermelstein, David. 1969. "Large industrial corporations and asset shares." American Economic Review 59:531-41.

Miliband, Ralph. 1969. The State in Capitalist Society. New York: Basic Books.

Mills, C. Wright. 1956. The Power Elite. New York: Oxford University Press.

Mintz, Beth. 1975. "The president's cabinet, 1897-1972: a contribution to the power structure debate." Insurgent Sociologist 5:131-48.

$\rightarrow$ Mintz, Beth, Peter Freitag, Carol Hendricks, and Michael Schwartz. 1976. "Problems of proof in elite research." Social Problems 23:314-24.

Mollenkopf, John. 1975. "Theories of the state and power structure research." Insurgent Sociologist 5:24564.

Parkin, Frank. 1971. Class Inequality and Political Order. New York: Praeger.

$\rightarrow$ Pfeffer, Jeffrey. 1972. "Size and composition of corporate boards of directors: the organization and its environment." Administrative Science Quarterly 17:218-28.

Poulantzas, Nicos. 1975. Political Power and Social Classes. Atlantic Highlands, N.J.: Humanities Press.

Prewitt, Kenneth, and William McAllister. 1976. "Changes in the American executive elite, 1930-1970.” Pp. 105-32 in Heinz Eulau and Moshe Czudnowski (eds.), Elite Recruitment in Democratic Politics. New York: Halsted Press.

Prewitt, Kenneth, and Alan Stone. 1973. The Ruling Elites. New York: Harper and Row.

Putnam, Robert. 1976. The Comparative Study of Elites. Englewood Cliffs, N.J.: Prentice-Hall.

Rose, Arnold M. 1967. The Power Structure. New York: Oxford University Press.

$\rightarrow$ Salamon, Lester and John Siegfried. 1977. "Economic power and political influence: the impact of industry structure on public policy." American Political Science Review 71:1026-43.

Scheuerman, William. 1975. "Economic power in the United States: the case of steel." Politics and Society $5: 337-66$.

Seider, Maynard. 1977. "Corporate ownership, control and ideology: support for behavioral similarity." Sociology and Social Research 62:113-28.

Shoup, Laurence. 1975. "Shaping the postwar world: the Council of Foreign Relations and U.S. war aims during WW II." Insurgent Sociologist 5:9-52.

Sonquist, John, and Thomas Koening. 1975. "Interlocking directorates in the top U.S. corporations: a graph theory approach." Insurgent Sociologist 5:196-229.

$\rightarrow$ Soref, Michael. 1976. "Social class and a division of labor within the corporate elite: a note on class, interlocking, and executive committee membership of directors of U.S. firms." The Sociological Quarterly 17: $360-68$.

Subcommittee on Governmental Affairs (U.S. Senate). 1978. Voting Rights in Major Corporations. Washington, D.C.: U.S. Government Printing Office.

$\rightarrow$ Walker, Jack. 1966. "A critique of the elitist theory of democracy." American Political Science Review 60: 285-95.

$\rightarrow$ Zald, Mayer. 1969. "The power and functions of boards of directors: a theoretical synthesis." American Journal of Sociology 75:97-111.

$\rightarrow$ Zuckerman, Alan. 1977. "The concept of political elite: lessons from Mosca and Pareto." Journal of Politics 39:324-44.

Zweingenhaft, Richard. 1975. "Who represents America." Insurgent Sociologist 5:119-30. 